Supplement of Hydrol. Earth Syst. Sci., 22, 4699-4723, 2018

https://doi.org/10.5194/hess-22-4699-2018-supplement

(c) Author(s) 2018. This work is distributed under

the Creative Commons Attribution 4.0 License.

(c) (1)

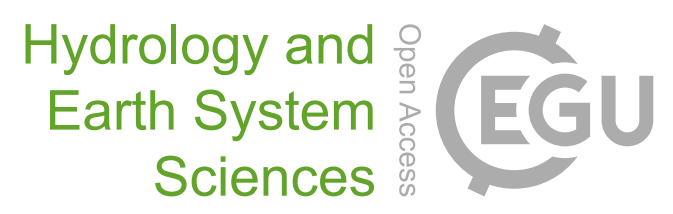

Supplement of

\title{
Modeling freshwater quality scenarios with ecosystem-based adaptation in the headwaters of the Cantareira system, Brazil
}

Denise Taffarello et al.

Correspondence to: Denise Taffarello (taffarellod@gmail.com, dt@sc.usp.br)

The copyright of individual parts of the supplement might differ from the CC BY 4.0 License. 
Supplement Table S1 - Gauging stations with field validated and observed data from 2004 to 2014.

\begin{tabular}{|c|c|c|c|c|c|c|c|}
\hline Source & Type & Code & City & State & Period & Latitude & Longitude \\
\hline USP/EESC & Field campaigns & Upper Posses & Extrema & MG & Dec/2012-May/2014 & -22.879 & -46.247 \\
\hline USP/EESC \& ANA & Field campaigns & Middle Posses ANA -62584500 & Extrema & MG & Dec/2012-May/2014 & -22.867 & -46.244 \\
\hline USP/EESC \& ANA & Field campaigns & Posses Outlet ANA - 62584600 & Extrema & MG & Dec/2012-May/2014 & -22.833 & -46.231 \\
\hline USP/EESC & Field campaigns & Salto Outlet & Extrema & MG & Dec/2012-May/2014 & -22.838 & -46.218 \\
\hline USP/EESC & Field campaigns & Upper Jaguari & Extrema & MG & Dec/2012-May/2014 & -22.820 & -46.154 \\
\hline USP/EESC & Field campaigns & Parque de Eventos & Extrema & MG & Dec/2012-May/2014 & -22.853 & -46.325 \\
\hline USP/EESC \& SABESP & Field campaigns & Tenentes F-23 & Extrema & MG & Jan/2004 - Jul/2014 & -22.827 & -46.314 \\
\hline USP/EESC & Field campaigns & Cachoeira dos Pretos & Joanópolis & SP & Dec/2012-May/2014 & -22.968 & -46.171 \\
\hline USP/EESC & Field campaigns & Chalé Ponto Verde & Joanópolis & SP & Dec/2012-May/2014 & -22.964 & -46.181 \\
\hline USP/EESC & Field campaigns & Cachoeira Bridge & Joanópolis & SP & Dec/2012-May/2014 & -22.968 & -46.171 \\
\hline USP/EESC \& SABESP & Field campaigns & Cachoeira Outlet F-24 & Joanópolis & SP & Jan/2004 - Jul/2014 & -22.983 & -46.244 \\
\hline USP/EESC & Field campaigns & Intervention Cancã & Joanópolis & SP & Dec/2012-May/2014 & -22.912 & -46.225 \\
\hline USP/EESC & Field campaigns & Reference Cancã & Joanópolis & SP & Dec/2012-May/2014 & -22.886 & -46.222 \\
\hline USP/EESC \& SABESP & Field campaigns & Cancã Outlet F-30 & Joanópolis & SP & Jan/2004 - Jul/2014 & -22.935 & -46.212 \\
\hline USP/EESC & Field campaigns & Intervention Moinho & NazaréPaulista & SP & Dec/2012-May/2014 & -23.222 & -46.325 \\
\hline USP/EESC & Field campaigns & Reference Moinho & NazaréPaulista & SP & Dec/2012-May/2014 & -23.232 & -45.323 \\
\hline USP/EESC \& SABESP & Field campaigns & Moinho Outlet & NazaréPaulista & SP & Dec/2012-May/2014 & -22.848 & -46.327 \\
\hline
\end{tabular}


Supplement Table S1 - Gauging stations with field validated and observed data from 2004 to 2014 (cont.).

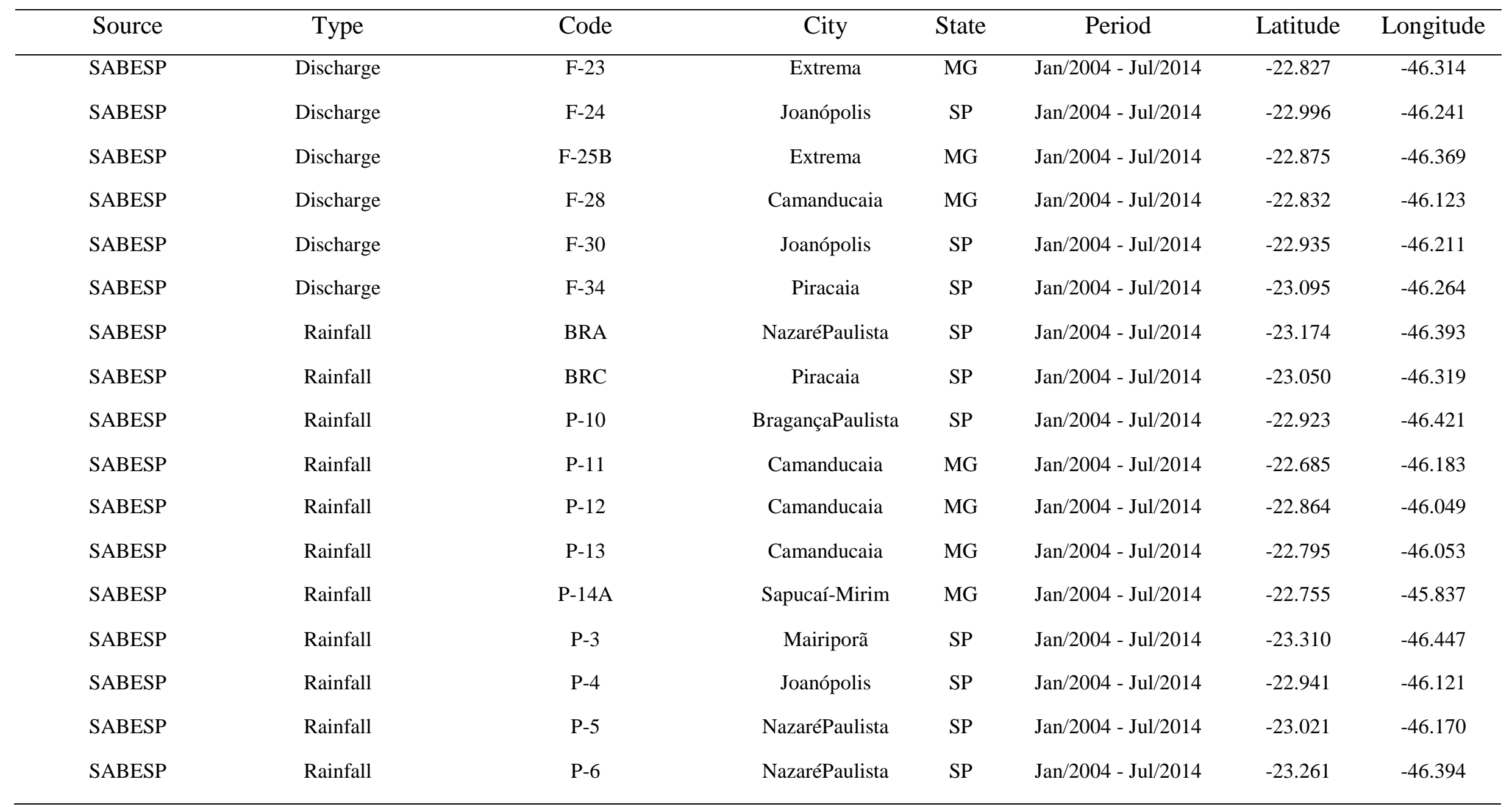


Supplement Table S1 - Gauging stations with field validated and observed data from 2004 to 2014 (cont.).

\begin{tabular}{|c|c|c|c|c|c|c|c|}
\hline Source & Type & Code & City & State & Period & Latitude & Longitude \\
\hline SABESP & Rainfall & P-7 & Joanópolis & SP & Jan/2004 - Jul/2014 & -22.994 & -46.242 \\
\hline SABESP & Rainfall & P-8 & Camanducaia & MG & Jan/2004 - Jul/2014 & -22.779 & -46.180 \\
\hline INMET & Weather & 83075 & Guarulhos & SP & Jan/2004 - Jul/2014 & -23.430 & -46.460 \\
\hline CPTEC/INPE & Weather & 83721 & Campinas & SP & Jan/2004 - Jul/2014 & -23.000 & -47.140 \\
\hline CIIAGRO & Rain and Temperature & at & Atibaia & SP & Jan/2004 - Jul/2014 & -23.083 & -46.560 \\
\hline CIIAGRO & Rain and Temperature & $\mathrm{bj}$ & Bom Jesus dos Perdões & SP & Jan/2004 - Jul/2014 & -23.131 & -46.450 \\
\hline CIIAGRO & Rain and Temperature & br & BragançaPaulista & SP & Jan/2004 - Jul/2014 & -22.949 & -46.525 \\
\hline CIIAGRO & Rain and Temperature & ex & Extrema & MG & Jan/2004 - Jul/2014 & -22.852 & -46.326 \\
\hline IGAM \& SABESP & Water quality & PJ021 e F-28 & $\begin{array}{l}\text { Camanducaia } \\
\text { (Monte Verde) }\end{array}$ & MG & Oct/2011 - Jul/2014 & -22.826 & -46.129 \\
\hline
\end{tabular}




\section{S.2 Secondary data used in this paper}

To reduce uncertainty about hydrological scaling effects of EbA through LULC scenarios from 2011 to 2014, we also collected supplementary, secondary data using three strategies. First, we scheduled interviews with local owners and farmers who explained their past, present and future (planned) best management practices (BMPs) related to Payment for Ecosystem Services-Water, derived from EbA initiatives of PCJ-Produtor de Agua Project of the Cantareira System's headwaters [Pagiola et al, 2013, Brazil's Experience with Payments for Environmental Services. Payments for Environmental Services (PES) learning paper; no. 2013-1. World Bank, Washington, DC, World Bank. https://openknowledge.worldbank.org/handle/10986/17854 License: CC BY 3.0 IGO]. This secondary information helped us to link LULC derived from EbA/PES-Water with some parameters of selected hydrologic response units (i.e. SWAT-HRUs). This surveillance on local knowledge brought a better understanding on physically-based parameters calibrated regionally, but with unsatisfactory coefficients in some catchments, i.e. Posses Catchment $\left(13-\mathrm{km}^{2}\right.$ drainage area). Second, we also collected secondary information about the scenarios' storylines from the multi-agent, multi-level governance of the PCJ-Produtor de Agua Project (municipality, state and national). Due to the states' border between Minas Gerais (MG) and São Paulo (SP), which have different reference standards, these multi-agent vision have strongly incluenced PES-Water/EbA practices across the transboundary (inter-state) nature of most Cantareira System's catchments. Thus, we undertook extra field visits to select sites, with higher uncertainty in modelling EbA and LULC scenarios, and to receive new flow gauging stations selected in companion with decision-makers representative of neighbor municipalities. We replicated these procedures in municipalities of Extrema-MG, Joanópolis-SP, Piracaia-SP and Nazaré Paulista-SP, and from state agencies (IGAM-MG, SMA-SP and DAEE-SP), and from federal agencies (ANA-The Brazilian Water Agency, CPRM- Brazilian Geologic Survey, and the National Center for Monitoring \& Alerts of Disasters, CEMADEN-MCTIC). Finally, we also consult non-government organizations (WWFBrazil, TNC-Brazil and local initiatives) (see Taffarello et al (2016-b), http://dx.doi.org/10.4236/jep.2016.712152). Third, the aforementioned strategies helped us to identify, select and prioritize qualitative and quantitative variables to reduce the uncertainties in the generation of pollutant loads under LULC, as proposed by other authors (see e.g. Zaffani et al, 2015; doi:10.4172/2161-0398.1000173, quoted in the references). These secondary data revealed the most viable conditions for nested catchment experiments to monitor experiments and test hypotheses through a scenario-intercomparison modelling of upstream areas of the Jaguari-Jacareí, Cachoeira and Atibainha reservoirs, and are updated regularly by official agencies with open access repositories of hydrological databases, such as ANA (http://hydroweb.ana.gov.br) and CEMADEN (http://www.cemaden.gov.br/pluviometros-automatico/)"

\section{S.3 Comments on sensitivity analysis to select model parameters used in this paper}

The selection of modelling parameters for water yield calibration was developed not only through consulting on SWAT literature [i.e. Arnold et al, 2012; Bressiani et al, 2015; Fukunaga et al, 2015; Gassman et al, 2007], but also by performing supervised analysis and comparing parameters from recent literature [i.e. Francesconi, W., R. Srinivasan, E. Pérez-Miñana, S.P. Willcock, M. Quintero. 2016]. "Using the Soil and Water 
Assessment Tool (SWAT) to model ecosystem services: A systematic review”, Journal of Hydrology 535 (2016) 625-636. DOI:10.1016/j.jhydrol.2016.01.034, and Monteiro, J. A. F., Kamali, B., Srinivasan, R., Abbaspour, K., and Gücker, B. (2016) "Modelling the effect of riparian vegetation restoration on sediment transport in a humanimpacted Brazilian catchment”, Ecohydrol., doi: 10.1002/eco.1726, now quoted]+and even from consultation of USP open access repository [see i.e. works of Rodrigues, 2014, www.teses.usp.br/teses/disponiveis/18/18138/tde-18122014-094354/pt-br.php; Bressiani, 2016 , www.teses.usp.br/teses/disponiveis/18/18138/tde-04042017-155701/pt-br.php, and Mohor, 2016, www.teses.usp.br/teses/disponiveis/18/18138/tde-23032017-102949/pt-br.php]. Firstly, in spite of a much larger list of suggested parameters for modelling goals proposed by Bressiani (2016; quoted), our regional sensitivity analysis followed the recommendations of the theory and practice of mapping ecosystem services using Tier 1 and Tier 2 models [see Mendoza et al, 2012, Ch. 3, in Kareiva et al(eds), 2012; ISBN 978-0-19-958899-2] constrained by the short time series monitored for all sites, with inequal quantitative assessment, seasonality and scale effects. Secondly, based on the studies carried out by Rodrigues et al [2014, doi:10.1002/2013WR014274, 2015, doi: 10.1002/2014WR016691], Bressiani et al [2015, doi: 10.3965/j.ijabe.20150803.1765] and Mohor \& Mendiondo [2017, doi: 10.1016/j.ecolecon.2017.04.014], we selected 18 SWAT parameters and their initial range of combinations, as follows: Available water capacity, Moist bulk density, Saturated hydraulic conductivity, Baseflow alpha factor, Threshold depth of shallow aquifer for return flow to occur, GW-Revap Coefficient, Groundwater delay time, Deep aquifer percolation fraction, Threshold depth of water in the shallow aquifer for "revap" or percolation to the deep aquifer to occur, Soil evaporation compensation factor, Plant uptake compensation factor, Manning's roughness for the main channel, Effective hydraulic conductivity in the main channel, Maximum canopy storage, Manning's “ $n$ ” for overland flow, Average slope steepness, Initial SCS CN (for antecedent moisture condition 2), and Surface runoff lag coefficient. Thirdly, in-situ field validation tests were developed through experimental campaigns to test the limits of variation of streamflow and water quality

\section{S.4 Comments on differences in land-use/land-cover in sub-basins studied}

Due to the significant variabilities among selected basins where in-situ monitoring was developed for EbA scenario purposes, and because we have not performed field validation in all distributed HRU (hydrologic response units), we decided not to show the regional results through maps. Whichever interpolation techniques would not be able to catch the inherent heterogeneity of LULC, neither in all HRUs with physically-based characteristics, nor of high-variability functionality of these subtropical catchments. Instead, we performed an initial analysis of clustering similar responses from catchments with the most plausible explanations as follows. On the one hand, evidence of SWAT modelled scenarios showed two groups of river basins under EbA scenarios, with distinct land use change of native forest fractions (NF\%). Our results show Group 1, with 11 of the studied basins, with native forest recovery using $\mathrm{EbA}(\mathrm{S} 2+\mathrm{EbA})$, as well as an intermediate land use fraction as follows: $\mathrm{NF} \%(\mathrm{~S} 2)<\mathrm{NF} \%(\mathrm{~S} 2+\mathrm{EbA})<\mathrm{NF} \%(\mathrm{~S} 1)$. In turn, Group 2 of 9 river basins showed a progressive growing fraction of native forests across scenarios, with best EbA land use impacts, as follows: $\mathrm{NF} \%(\mathrm{~S} 1)<$ $\mathrm{NF} \%(\mathrm{~S} 2)<\mathrm{NF} \%(\mathrm{~S} 2+\mathrm{EbA})$. The basins from Group 1 are mainly located close to both urban settlements and Eucaliptus plantations in Northwestern headwaters, where conservation projects through EbA have small 
adherence in LULC and in SWAT outputs (see Figure 3). Moreover, the catchments from Group 1 are mainly located in Eastern and Southeastern areas (Figure 3), where there are more EbA projects of PCJ-Produtor de Agua. On the other hand, greater impacts in water yield are inversely correlated with land-uses and water pollutant quality, but with high non-linear relationships and without explicit regional factors (see Figure 11). For an integrated assessment of hydro-services, it is worth noting that phosphorus, nitrate and sediment yields have spatio-temporal changes of load production across scenarios S1, S2 and S2+EbA, which would be better understood in selected catchments, namely Alto Jaguari and Domithildes.

\section{S.5 Comments of reasons for selecting specific catchments for discussion}

The two catchments (see Sections 3.4.1 and 3.4.2 of the main text) were selected regarding the different groups identified in this study, forementioned, contrasting the outputs from 20 sites: Upper Jaguari is selected from Group 1 and Domithildes is selected from Group 2. Moreover, we studied the following variables in these two selected catchments. First, we analyzed the fraction of water yield affected by the grey water footprint for nitrate (ca. 0.08 to $3.9 \mathrm{mg} / \mathrm{L}$ ), total phosphorous (from 0.02 to $1.2 \mathrm{mg} / \mathrm{L}$ ) and sediments (approx. 0.03 to 250 $\mathrm{mg} / \mathrm{L}$ ). These concentrations represented dilution demands between $0.1 \%$ to close to $1000 \%$ of simulated water yield for a wide range, in between 10 to $500 \mathrm{~km}^{2}$ [see Figure 12 of the paper]. Second, these demands depended on: the native forest cover [i.e. in Figure 9, with S1 for year 1990, S2 for year 2010 and S2+EbA for year 2035], the flow duration curves under three LULC scenarios at 20 headwaters [Fig. 10], and the scaling effects of EbA actions on drainage areas [ranging from the small Domithildes catchment of $9.9 \mathrm{~km}^{2}$ to the medium-sized Alto Jaguari catchment of $302 \mathrm{~km}^{2}$ ]. These factors clearly affected (a) the fraction of water yield affected by the GWF$\mathrm{NO}_{3}$, GWF-TP and GWF-Sed, and (b) the reference flows in duration curves, both in streamflow and in pollutant loads, especially for low-flows (higher duration probabilities [see Fig. 13 and 14]. Moreover, the annual regime of water yield of these two selected catchments revealed local constraints in the size of catchments ranging from 10 to $300 \mathrm{~km}^{2}$. Thus, we pointed what limits for SWAT modeling when using the EbA assessment and PESWater projects through GWF, ranging from GWF-NO3 below $0.2 \mathrm{~m}^{3} / \mathrm{s}$ to GWF-TP up to $20 \mathrm{~m}^{3} / \mathrm{s}$. These results converged with the general discussion with blue and green water accounting shown in the studies carried out by Rodrigues et al [2014; A blue/green water-based accounting framework for assessment of water security, Water Resour. Res., 50, 7187-7205, doi:10.1002/2013WR014274].

The evidence we modelled using SWAT concerning GWF and LULC was presented in Section 3.4. "Relationships between land-use/land-cover change and grey water footprint" of the main text of the paper. These results are regarded to regional-averaged values (20 catchments), using the same test period (8-yr time series tested) and with fixed time-step modelled (SWAT monthly-basis). On the one hand, native forest land use fractions (NF\%) have ranges of $41 \pm 14,39 \pm 15 \%$ and $44 \pm 16 \%$, and were related to GWF-NO3 of $0.68 \pm 0.6$, $0.28 \pm 0.1$, and $0.44 \pm 0.1$, for $S 1(1990), S 2(2010)$ and $S 2+\operatorname{EbA}(2035)$ scenarios, respectively. On the other hand, land use fraction with high-stand vegetation (native, eucaliptus and orchard) ranged between 46\%, 53\% and 62\% for the same scenarios, respectively, not showing a trend. For GWF-TP and GWF-Sed, the values differ in absolute terms and the averaged ratios of GWF/Water Yield also changed. In spite of the high variability of 
responses, and small period of testing, we recommend future field campaigns and further multivariate statistical analysis, but they are out of the scope of the present paper.

\section{S.6 Comments on the limits of hydrological simulation during low-flow and drought periods}

We decided to insert this new section in the Supplementary Material to attend the comments made by one reviewer of this paper as follows: "As one-third of the SWAT simulation are low-flow or drought years. It is known that SWAT model is weak in capturing extreme flows. One of the reasons for the discrepancy between monitoring data and model simulation might not the weakness of the SWAT model to represent low-flows?".

We agree with these comments. On the one hand, recent papers addressing a review of SWAT applications in Brazil outlined the challenges and prospects to reduce the discrepancies between monitoring data and existing (regional) literature and model simulations [i.e. Bressiani et al, 2015; doi: 10.3965/j.ijabe.20150803.1765], quoted in the references. This general review is useful to address model discrepancies in a multilevel approach: quantitative water yield, water quality loads and rainfall-streamflow behaviours at a range of scales during the same period of monitoring and the inherent streamflow variability at these subtropical catchments. Due to this, our strategy selected sites through a nested catchment experiment to study these discrepancies according to the natural hydrological cycle, when possible. On the other hand, we addressed these discrepancies by quantitative calibration with a consecutive freshwater quality calibration. Our evidence showed [see i.e. Fig. 5] that at some drainage areas, between $12 \mathrm{~km}^{2}$ to $508 \mathrm{~km}^{2}$, the SWAT model might underestimate observed streamflows. Even in three field-campaigns, freshwater quality $\left(\mathrm{NO}_{3}\right)$ simulation did perform close to SWAT model runs. But in the May, 2014 campaign we denoted a higher departure between field validation and SWAT modelling, probably because of SWAT limitation of updating new water quality parameters with the rainfall anomaly, with an extended period with drought as pointed in quoted papers of Taffarello et al [2016-a; doi: $\underline{\text { 10.1080/02508060.2016.1188352 ] and Mohor \& Mendiondo (2017; doi: 10.1016/j.ecolecon.2017.04.014] }}$

\section{S.7 Possible reason for model underperformance for some sub-basins}

As mentioned in the paper, both the Posses catchment and Cachoeira catchment have been constrained by limitations in SWAT modeling set-ups because of: anthropic and illegal domestic water withdrawals across riversides and margins, with small dams affecting the streamflow regime and in some cases, Eucaliptus sp planted close to river channel during low-flows. Taffarello [2016-a, quoted] showed this in the open-access repository pictures, which described anthropic impacts on water yield and water withdrawal [see Open Repository at www.teses.usp.br/teses/disponiveis/18/18138/tde-05042017-091421/pt-br.php]. These human-made impacts strongly affected the SWAT underperformance in calibration and validation steps, not only on NASH, NASH$\log$ but also on the PBIAS, especially after long periods of droughts or rainfall anomalies [see Figure 5, this paper]. Because these human-made interferences come from real situations at catchments studied, without special SWAT parameterization and scaling from HRU to the whole catchments, we decided not to reduce both complexity and heterogeneity through a complete, exhaustive sensitivity analysis of SWAT parameters. Thus, we recommend further studies along these lines if new and more field evidence from other catchments is available. 
Futhermore, the main objective of this paper is not to address sensitivity analysis among SWAT parameters. Instead, we aimed to perform hypothesis tests of scenario inter-comparisons, including EbA policies and PES-Water actions, using SWAT pre-calibrated parameters, linked with previous field evidence collected during sampling periods and previous modelling experiences in these basins [i.e. Rodrigues et al, 2014, doi: 10.1002/2013WR014274; Rodrigues et al, 2015; Bressiani et al, 2015, DOI: 10.1002/2014WR016691; Taffarello et al, 2016-a, DOI:10.1080/02508060.2016.1188352; Mohor \& Mendiondo, 2017, DOI: 10.1016/j.ecolecon.2017.04.014]. As one of the first Brazilian contributions of coupling EbA directives into hydrological modelling using nested catchment experiments and monitoring in the Brazilian Atlantic Forest [see i.e. Taffarello et al, 2016-b, DOI: 10.1016/j.cliser.2017.10.005, quoted], this paper could promote other research groups which might develop further modelling hypotheses.

Regarding the sensitivity analysis, as questioned, we proceeded with the calibration process, although not exhaustive. Given that SWAT has a very large number of parameters and our experiment involved nested catchments, rather than a single experimental basin, testing an exhaustive sensitivity analysis of all parameters in our study case with EbA is out of the scope of the paper. We consulted previous applications of SWAT in the literature, preferably those in Brazilian basins, to find the most indicated parameters to work on. Based on Fukunaga et al. [2015, DOI: 10.1016/j.catena.2014.10.032], Gassman et al. [2007, DOI: 10.13031/2013.23637], Arnold et al. [2012, DOI: 10.13031/2013.42256] and a good review by Bressiani et al. [2015, quoted], we firstly selected 18 SWAT parameters with their initial ranges by Rodrigues et al [2014, 2015 quoted]. Then, we made analyses of these 18 parameters in the catchments at headwaters of Cantareira Sysem. After analyzing these preview results, we chose to re-calibrate some parameters in some basins. Thus, SWATCUP was performed in our tests, with each cycle consisting of 300 runs. In each cycle, we reached new limits for each parameter or even stopped tuning a parameter. The number of cycles varied among the sub-basins, from one to 5 cycles. From all the 20 nested catchments studied in the Cantareira System and using the initial 18 SWAT parameters, some tested catchments permitted the calibration of only 7 parameters, while other catchments permitted the calibration of 17 (of the original 18) parameters. From upstream to downstream, after the automatic step, a manual calibration refinement also took place. One example of the range of the final values is shown below in Supplement Table S.2. 
Supplement Table S.2 - Selected SWAT parameters for supervised calibration and initial sensitivity analysis

\begin{tabular}{|c|c|c|c|c|c|c|}
\hline Parameter* & $\begin{array}{c}\text { Initial } \\
\text { (min.value) }\end{array}$ & $\begin{array}{c}\text { Median }^{1} \\
\text { (min. value) }\end{array}$ & $\begin{array}{c}\text { Selected) } \\
\text { (min. value) }\end{array}$ & $\begin{array}{c}\text { Selected } \\
\text { (max.value) }\end{array}$ & $\begin{array}{c}\text { Median }^{1} \\
\text { (max.value) }\end{array}$ & $\begin{array}{c}\text { Initial } \\
\text { (max.value) }\end{array}$ \\
\hline a_CANMX.hru & 0 & 0 & 0 & 100 & 60 & 100 \\
\hline a__Ch_N2.rte & -0.0005 & 0 & 0 & 0.28 & 0.3 & 0.3 \\
\hline a__CN2.mgt & -15 & -12 & -8.67 & 10.31 & 10 & 15 \\
\hline a_GW_DELAY.gw & -15 & -3 & -4.161 & 42.69 & 30 & 50 \\
\hline & & & - & & & \\
\hline a_GWQMN.gW & -550 & -300 & 415.02 & 360.00 & 350 & 450 \\
\hline r_OV_N.hru & -0.5 & dismissed & & - & dismissed & 1 \\
\hline r_SHALLST.gw & -0.5 & -0.3 & -0.08 & 0.39 & 0.4 & 0.6 \\
\hline r_SOL_AWC().sol & -0.5 & -0.25 & -0.42 & 0.29 & 0.33 & 0.5 \\
\hline r__SOL_BD(1).sol & -0.2 & -0.15 & -0.19 & 0.18 & 0.2 & 0.4 \\
\hline r_SOL_K().sol & -0.4 & -0.27 & -0.32 & 0.35 & 0.37 & 0.5 \\
\hline v_Alpha_BF.gw & 0.01 & 0.02 & 0.001 & 0.049 & 0.05 & 0.1 \\
\hline $\mathrm{v} \_\mathrm{Ch} \_\mathrm{K} 2 . \mathrm{rte}$ & 0 & 0 & 0 & 36.74 & 30 & 130 \\
\hline v__EPCO.hru & 0.4 & 0.4 & 0.85 & -2 & 1 & 1 \\
\hline v_ESCO.hru & 0.4 & 0.7 & 0.69 & 0.95 & 0.95 & 0.95 \\
\hline v_GW_REVAP.gw & 0.02 & 0.02 & 0.01 & 0.18 & 0.2 & 0.2 \\
\hline v_RCHRG_DP.gw & 0.01 & 0.01 & 0.05 & 0.68 & 0.5 & 1 \\
\hline v__REVAPMN.gw & 0 & 500 & 539.28 & 959.28 & 1000 & 1000 \\
\hline v__SURLAG.hru & 0.01 & 1.5 & 0.97 & 5.53 & 4 & 5 \\
\hline IPET & & & (0) & tley-Taylor & & \\
\hline
\end{tabular}

Legends: "1": "median" of the limits adopted in following runs in SWAT-CUP. Manual calibration could overcome these limits; "2": only one sub-basin had EPCO modified. * a_stands for "added" value, i.e. the final value in each feature (e.g. each HRU) is the original value plus the calibrated coefficient; $r_{-}$stands for ratio, i.e. the final value in each feature is the original value times $1+$ the calibrated coefficient; $v_{-}$stands for value, i.e. the final value of the feature is the calibrated coefficient. Source: after field visits, these parameters' range were adapted for specific catchments from the open repositories of Mohor [2016; www.teses.usp.br/teses/disponiveis/18/18138/tde-23032017-102949/pt-br.php], Bressiani [2016; www.teses.usp.br/teses/disponiveis/18/18138/tde-04042017155701/pt-br.php] and Rodrigues [2014; http://www.teses.usp.br/teses/disponiveis/18/18138/tde-18122014-094354/pt-br.php] 
Finally, we followed a step-by-step, but not exhaustive, calibration procedure using collection and assessment of data, understanding the watersheds, identifying and selecting sites and periods to calibrate and validate, defining calibration methods, objective functions and evaluation metrics, main water balance components, with volumes and process representations, defining parameters and ranges of variability, sensitivity analysis, calibration, validation, cross validation and uncertainty analysis (Bressiani, 2016, quoted; Mohor, 2016, quoted). As previously mentioned, we also consulted former SWAT modelling strategies used in these basins, available in the open repository by Mohor [2016; www.teses.usp.br/teses/disponiveis/18/18138/tde-23032017102949/pt-br.php], Bressiani [2016; www.teses.usp.br/teses/disponiveis/18/18138/tde-04042017-155701/ptbr.php] and Rodrigues [2014; http://www.teses.usp.br/teses/disponiveis/18/18138/tde-18122014-094354/ptbr.php]. In our paper, we addressed a calibration stage of SWAT-CUP (Calibration and Uncertainty Programs) software and SUFI-2 (Sequential Uncertainty Fitting) method. SUFI-2 is based on Latin Hypercube sampling [Abbaspour et al, 2015; quoted in the references). After this automatic stage, a finer adjustment using manual calibration was made, following the recommendations of Mohor (2016) and Mohor \& Mendiondo (2017; DOI: 10.1016/j.ecolecon.2017.04.014), quoted in the references. For more in-depth sensitivity analysis of SWAT parameters, we recommend Bressiani (2016) who proposed not only a new systematic procedure for calibrating the SWAT model in complex basins, but also a search for a better SWAT performance and reduced optimization time, using different calibration methods on different watershed locations. Moreover, Rodrigues [2014, Table 2.3, page 56] adjusted some parameters for nested catchments in the Cantareira System (CN2, Canmx, OV_N, SOL_K, SOL_AWC), according to land use classes.

\section{S.8 Comments on the representativeness of intrannual sampling of freshwater quality: turbidity}

During the 2013/2014 field campaigns across all the nested catchments presented here, the turbidity ranged between extremes of 1 and 300 NTU, with median values close to 11 NTU. These high variability captured ranges of in-situ monitored instantaneous mean cross-section velocities below $1 \mathrm{~m} / \mathrm{s}$ and specific streamflows ca. 0.001 to $0.025 \mathrm{~m}^{3} / \mathrm{s} / \mathrm{km}^{2}$. These values captured approximate flow discharges in the range of $5 \%$ and $96 \%$ of probability of regional flow duration curves, and also affected the variability of the turbidity of water quality. Moreover, these ranges were observed during the 2013/2014 anomalous rainy season, alternating heavy rains and dry periods, in both reference catchments with EbA initiatives and impacted catchments with land-use changes. Due to this, we understand, in spite of having sampled only 8 months of monitoring, observed turbidity is not biased and could represent the conditions for using EbA hypothesis for the scenarios we tested. More details of experimental sampling and observational schemes are explained in Taffarello et al [2016-a; quoted] 
Supplement Table S.3 - LULC changes in headwaters of the Cantareira System for scenarios of S1 (LULC in 1990), S2 (LULC in 2010) and S2+EbA (LULC in 2035) with correspondent HSI(2035).Asterisk depicts critical or less sustainable catchment according to HSI(2035).

\begin{tabular}{|c|c|c|c|c|c|c|c|c|c|}
\hline \multirow{2}{*}{$\begin{array}{l}\text { Sub- } \\
\text { basin }\end{array}$} & \multirow[t]{2}{*}{ Gauge station } & Hydrologic & \multirow{2}{*}{$\begin{array}{l}\text { Drainage } \\
\text { area }\left(\mathrm{km}^{2}\right)\end{array}$} & \multirow{2}{*}{$\begin{array}{r}\text { Equivalent } \\
\text { scenario } \\
\text { timeline }\end{array}$} & \multicolumn{5}{|c|}{ Land-Use/Land-Cover (\% of drainage area) } \\
\hline & & $\begin{array}{l}\text { Service Index - } \\
\text { HSI (2035) }\end{array}$ & & & $\begin{array}{r}\text { Native } \\
\text { forest }\end{array}$ & $\begin{array}{l}\text { Euca- } \\
\text { lypto }\end{array}$ & Pasture & $\begin{array}{l}\text { Agri- } \\
\text { culture }\end{array}$ & Urban \\
\hline \multirow[t]{2}{*}{1} & Upper Jaguari & not applied & 302.20 & 1990 & 47.0 & 6.0 & 35.0 & 12.0 & 0.0 \\
\hline & & -0.99 (sustainable) & & 2035 & 66.2 & 21.1 & 8.2 & 4.6 & 0.3 \\
\hline \multirow[t]{2}{*}{2} & $\mathrm{~F} 23 *$ & not applied & 508.10 & 1990 & 37.0 & 2.0 & 52.0 & 9.0 & 0.0 \\
\hline & & not applied & & 2010 & 34.0 & 2.0 & 44.0 & 19.0 & 0.0 \\
\hline \multirow{2}{*}{3} & & not applied & & 2010 & 69.0 & 22.9 & 6.9 & 3.0 & 0.0 \\
\hline & & -0.99 (sustainable) & & 2035 & 69.1 & 21.3 & 6.9 & 3.3 & 0.3 \\
\hline \multirow[t]{3}{*}{4} & Salto & not applied & 15.06 & 1990 & 40.0 & 1.0 & 50.0 & 9.0 & 0.0 \\
\hline & & not applied & & 2010 & 29.0 & 2.0 & 53.0 & 16.0 & 0.0 \\
\hline & & -0.99 (sustainable) & & 2035 & 31.5 & 2.4 & 50.5 & 15.5 & 0.0 \\
\hline \multirow{2}{*}{6} & & not applied & & 2010 & 13.0 & 1.0 & 70.0 & 16.0 & 0.0 \\
\hline & & +0.44 (critical) & & 2035 & 15.6 & 0.7 & 70.2 & 13.5 & 0.0 \\
\hline \multirow[t]{3}{*}{7} & Portal Estrelas* & not applied & 7.17 & 1990 & 24.0 & 0.0 & 62.0 & 14.0 & 0.0 \\
\hline & & not applied & & 2010 & 15.0 & 1.0 & 72.0 & 12.0 & 0.0 \\
\hline & & +1.42 (critical) & & 2035 & 17.1 & 0.6 & 70.5 & 11.8 & 0.0 \\
\hline \multirow[t]{3}{*}{8} & F25B* & not applied & 971.90 & 1990 & 33.0 & 2.0 & 50.0 & 10.0 & 5.0 \\
\hline & & not applied & & 2010 & 38.0 & 1.0 & 43.0 & 13.0 & 5.0 \\
\hline & & +0.37 (critical) & & 2035 & 45.5 & 7.9 & 32.3 & 13.5 & 0.8 \\
\hline \multirow[t]{3}{*}{9} & Domithildes & not applied & 9.93 & 1990 & 51.0 & 0.0 & 37.0 & 12.0 & 0.0 \\
\hline & & not applied & & 2010 & 52.0 & 5.0 & 30.0 & 13.0 & 0.0 \\
\hline & & 0.00 (reference) & & 2035 & 56.4 & 4.6 & 27.3 & 11.7 & 0.0 \\
\hline & & -0.90 (sustainable) & & 2035 & 58.9 & 20.1 & 15.3 & 5.7 & 0.0 \\
\hline 13 & Chale Pt: Verde & not applied & 107.90 & 1990 & 39.0 & 8.0 & 46.0 & 7.0 & 0.0 \\
\hline & & not applied & & 2010 & 29.0 & 31.0 & 30.0 & 10.0 & 0.0 \\
\hline & & -0.93 (sustainable) & & 2035 & 62,1 & 21.5 & 11.0 & 5.1 & 0.0 \\
\hline 14 & Cachoeira dos & not applied & 101.20 & 1990 & 59.0 & 8.0 & 27.0 & 6.0 & 0.0 \\
\hline & Pretos & not applied & & 2010 & 66.0 & 20.0 & 9.0 & 5.0 & 0.0 \\
\hline & & -0.96 (sustainable) & & 2035 & 66.2 & 20.3 & 8.7 & 4.6 & 0.0 \\
\hline 15 & B: Jacareí* & not applied & 200.50 & 1990 & 32.0 & 0.0 & 52.0 & 13.0 & 2.0 \\
\hline & & not applied & & 2010 & 39.0 & 5.0 & 42.0 & 13.0 & 2.0 \\
\hline & & +5.27 (critical) & & 2035 & 32.7 & 2.7 & 32.1 & 10.3 & 2.0 \\
\hline 16 & F24 & not applied & 293.50 & 1990 & 56.0 & 4.0 & 32.0 & 8.0 & 0.0 \\
\hline & & not applied & & 2010 & 47.0 & 18.0 & 25.0 & 9.0 & 0.0 \\
\hline & & -0.31 (sustainable) & & 2035 & 53.2 & 17.8 & 21.3 & 7.7 & 0.0 \\
\hline 17 & B: Cachoeira* & not applied & 391.70 & 1990 & 35.0 & 6.0 & 47.0 & 11.0 & 0.0 \\
\hline & & not applied & & 2010 & 42.0 & 21.0 & 27.0 & 10.0 & 0.0 \\
\hline & & +0.12 (critical) & & 2035 & 50.1 & 18.1 & 22.0 & 7.9 & 0.0 \\
\hline 18 & F34 & not applied & 129.20 & 1990 & 59.0 & 9.0 & 23.0 & 9.0 & 0.0 \\
\hline & & not applied & & 2010 & 61.0 & 19.0 & 10.0 & 10.0 & 0.0 \\
\hline & & +2.46 (critical) & & 2035 & 61.4 & 19.3 & 9.9 & 9.3 & 0.0 \\
\hline 19 & B.Atibainha* & not applied & 313.80 & 1990 & 49.0 & 7.0 & 30.0 & 13.0 & 0.0 \\
\hline & & not applied & & 2010 & 60.0 & 18.0 & 13.0 & 9.0 & 0.0 \\
\hline
\end{tabular}


+1.13 (critical)

not applied

not applied

+2.05 (critical)
2035

1990

2010

2035
56.3

46.0

49.0

49.9
17.5

10.0

22.0

21.4
10.8

27.0

17.0

16.2
8.8

17.0

13.0

12.5 0.0
0.0 
Supplement Table S.4: Maximum and minimum values of variables observed during field campaigns of Oct, 2013 - May, 2014 in the headwaters of the Cantareira System, Southeast Brazil.

\begin{tabular}{|c|c|c|c|c|c|c|c|c|c|c|c|c|}
\hline \multirow[b]{2}{*}{ Sub-basin } & \multicolumn{2}{|c|}{ Flow discharge } & \multicolumn{2}{|c|}{ Electrical conductivity } & \multicolumn{2}{|c|}{$\mathrm{pH}$} & \multicolumn{2}{|c|}{ BOD } & \multicolumn{2}{|c|}{ COD } & \multicolumn{2}{|c|}{ E: Coli } \\
\hline & $\begin{array}{l}\text { MIN: } \\
\left(\mathrm{m}^{3} / \mathrm{s}\right)\end{array}$ & $\begin{array}{l}\text { MAX: } \\
\left(\mathrm{m}^{3} / \mathrm{s}\right)\end{array}$ & $\begin{array}{r}\mathrm{MIN} \\
(\mu \mathrm{S} / \mathrm{cm})\end{array}$ & $\begin{array}{r}\text { MAX } \\
(\mu \mathrm{S} / \mathrm{cm})\end{array}$ & MIN. & MAX. & $\begin{array}{r}\text { MIN } \\
(\mathrm{mg} . / \mathrm{L})\end{array}$ & $\begin{array}{r}\text { MAX } \\
(\mathrm{mg} / . \mathrm{L})\end{array}$ & $\begin{array}{r}\text { MIN } \\
(\mathrm{mg} / . \mathrm{L})\end{array}$ & $\begin{array}{r}\text { MAX } \\
\text { (mg./L) }\end{array}$ & $\begin{array}{l}\text { MIN } \\
\text { (ufc) }\end{array}$ & $\begin{array}{r}\text { MAX } \\
\text { (ufc) }\end{array}$ \\
\hline Middle Posses & 0,031 & 0,082 & 53 & 63 & 6,8 & 7,0 & $<1$ & $<1$ & 8 & 26 & 14 & 260 \\
\hline OutletPosses[*] & 0,039 & 0,107 & 65 & 133 & 6,7 & 7,1 & 2 & 2 & 5 & 24 & 1 & 2000 \\
\hline $\mathrm{F} 23$ & 1,706 & 5,500 & 44 & 60 & 6,7 & 6,9 & 6 & 6 & 18 & 48 & 17 & 3600 \\
\hline Upper Jaguari & 1,387 & 6,283 & 23 & 59 & 6,9 & 7,0 & 2 & 2 & 2 & 28 & 2 & 100 \\
\hline Parque de Eventos & 4,568 & 20,689 & 38 & 50 & 6,6 & 6,9 & 2 & 6 & 11 & 36 & 31 & 4100 \\
\hline Ponte Cachoeira & 1,400 & 3,618 & 15 & 20 & 6,3 & 7,0 & 2 & 3 & 6 & 26 & 340 & 4000 \\
\hline F24 & 2,250 & 5,174 & 22 & 28 & 6,7 & 6,9 & 2 & 4 & 10 & 34 & 5 & 690 \\
\hline $\begin{array}{l}\text { Intervention } \\
\text { Cancã }[* *]\end{array}$ & 0,005 & 0,022 & 39 & 48 & 6,7 & 7,0 & 3 & 3 & 3 & 22 & 40 & 730 \\
\hline $\begin{array}{l}\text { Reference } \\
\text { Cancã [**] }\end{array}$ & 0,002 & 0,009 & 42 & 48 & 6,6 & 7,1 & 2 & 2 & 5 & 27 & 5 & 650 \\
\hline $\mathrm{F} 30\left[{ }^{*}\right]$ & 0,641 & 1,297 & 36 & 40 & 6,8 & 7,1 & 3 & 4 & 9 & 42 & 140 & 3400 \\
\hline
\end{tabular}

Legend: * indicates new data collection stations installed for experimental monitoring according to ANA/CPRM standards; ** indicates experimental stations for research purposes. Source: Taffarello et al (2016-a)

\section{S.9 Summary of monitored and modelled water yield scenarios}

Figure S1 depicts a summary of monitored and modelled water yield observations and scenarios compared with EbA and GWF outputs in the catchments studied at the Cantareira System. The main bold, vertical, dotted line represents the regional mean water yield, compared with water yields from simulated scenarios, also including their respective GWFs. This figure clearly points out six different conditions, labelled with letters (A, $\mathrm{B}, \mathrm{C}, \mathrm{D}, \mathrm{E}$ and $\mathrm{F}$ ), which configurate potential scenarios of water security according to land-use change and insecurity thresholds, also showing tradeoffs between the water yield and grey water footprint outputs, explained in the text. 


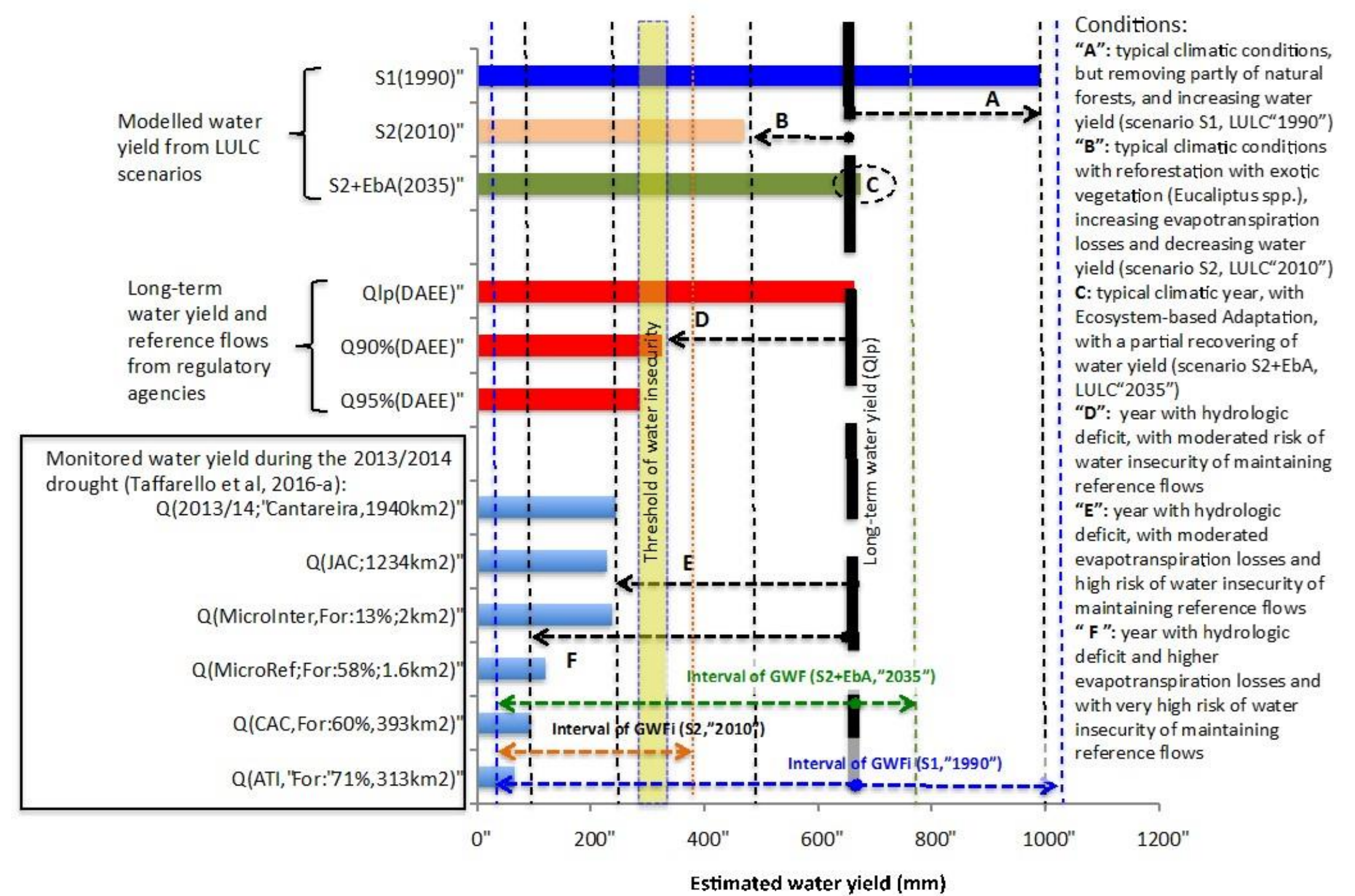

Supplementary Figure S.1: Summary of monitored and modelled water yield (horizontal axis), compared with ecosystem-based adaptation and grey water footprint in the headwaters of the Cantareira System, Brazil. Upper bars represent modelling freshwater quality scenarios ("blue": S1, 1990; "orange": S2, 2010; and "green": S2+Eba, 2035). Middle red bars depict regionalized long-term water yield (Qlp) and reference flows of duration curves (Q90\% and Q95\%) regarding Brazilian regulatory agencies (DAEE, 1988). Lower blue bars depict monitored water yield in several catchments of Cantareira System during the 2013/14 drought (see Taffarello et al, 2016-a). Intervals of greyWF of scenarios are also plotted. Bold, capital letters (“A", "B", "C", "D", "E"), showing different conditions for water security using deviations from regionalized long-term water yield (Qlp) for the headwaters of Cantareira System, Brazil. 